\title{
研究報文
}

\section{傾斜回転目皿式播種機を利用したダイズの高速播種技術 一高速播種用傾斜回転目皿の開発一}

\author{
国立卓生 \\ (独) 農研機構中央農業総合研究センター

\begin{abstract}
High-Speed Seeding with an Inclined-plate Soybean Seeder
\end{abstract} \\ -Development of the Inclined Cell Plate-
}

Takuo KOKURYu

National Agricultural Research Center, NARO

\section{1. 緒言}

平成 22 年 3 月に閣議決定された「食料・農業・ 農村基本計画」によると，国産ダイズの作付面積 は, 平成 20 年度の 15 万 ha から平成 32 年度 30 万 ha と倍増が計画されており（農林水産省 2011）, この数值目標を実現するには水田の団地的な利用 や大型トラクタの導入などにより作業の効率化を 図ることが不可欠である。とくに，国内のダイズ 作は湿潤な水田輪換畑での作付けが約 9 割を占め ること，播種時期が梅雨と重なることから，限ら れた期間内に効率的に播種作業を行う必要があ り，播種作業の高速化が不可欠である.

一方，播種作業を高速化する場合，ダイズ作で 広く普及する傾斜回転目皿式播種機（以後, 目血 式播種機）では播種穴に種子が供給されず，播種 粒数が低下しやすい課題があり (小嶋ら 1966), 現 在，普及する市販の目皿式播種機（アグリテク， 矢崎製クリーンシーダ) では, 作業速度 $0.8 \mathrm{~m} / \mathrm{s}$ 以 上に達すると播種粒数が低下する（岩㴊ら 2006, 皆川2008).

しかしながら，近年は大型トラク夕の導入など によって播種作業が高速化し，作業速度は1.0

平成 23 年 4 月 13 日受付

平成 23 年 7 月 26 日受理

Corresponding author

国立卓生 Takuo KOKURYU

干305-8666 茨城県つくば市観音台 3-1-1

3-1-1, Kannondai, Tsukuba, Ibaraki, 350-8666, Japan

E-mail : koku@affrc.go.jp
$1.5 \mathrm{~m} / \mathrm{s}$ 程度が望まれている。このため, 播種作業 の高速化に対応した傾斜回転目皿（以後，傾斜目 皿）の開発が不可欠である.

そこで本研究では, 高速播種用傾斜目皿を開発 するにあたり, 播種粒数は播種穴周速度が遅いほ ど低下しにくいこと（常松ら 1958, 小嶋ら 1966, 下 名迫ら 1989), しかしながら, 市販品む含め, 播種 穴は播種穴周速度の速い外周付近に固定されてい ること(岡村ら 1966, 永田ら 1989, 下名迫ら 1989), 傾斜目皿の中心から播種穴の中心までを半径とし た円の直径（以後，播種穴ピッチ円の直径）之播 種粒数の関係はこれまで検討されていないことに 着目した，播種穴周速度を低下させるためには， 播種穴ピッチ円の直径を小さくすることが有効で ある。

但し，播種穴を傾斜目皿の中心よりに配置する 之，外側に配置した場合と比べて播種穴を通過す る種子の割合が低下したり, 播種穴と種子の接触 距離が短くなるので，播種穴周速度を落としても 播種粒数が低下する可能性がある.

本報では, 市販の目皿式播種機による播種作業 の高速化を実現するため，まず，試作した室内実 験装置を用いて播種穴ピッチ円の直径が播種粒数 に及ぼす影響を調べた。この際, 播種穴の直径 (以後, 穴径) や傾斜目皿の厚さ, 播種穴周速度と の関係屯調べた。つづいて, 高速播種用傾斜目皿 を試作し，その性能を室内と圃場において調べ た. 


\section{2. 材料及び方法}

1）室内試験

（1）供試材料

本研究で供試した種子は, ‘夕チナガハ’ (以後, 大粒）および ‘Bragg’（以後，小粒）とした。粒径 （100 粒平均值）は，大粒が，長さ 8.72 土標準偏差 $0.42 \mathrm{~mm}$ (最小 7.86 ～最大 $9.66 \mathrm{~mm}$ ), 幅 8.34 土 $0.31 \mathrm{~mm}(7.76 \sim 8.92 \mathrm{~mm})$, 厚さ (以後, 粒厚) 7.16 $\pm 0.42 \mathrm{~mm}(6.27 \sim 7.98 \mathrm{~mm})$ であった。また小粒 は, 長さ $7.19 \pm 0.36 \mathrm{~mm}(6.10 \sim 7.88 \mathrm{~mm})$, 幅 6.77 $\pm 0.35 \mathrm{~mm}(5.76 \sim 7.59 \mathrm{~mm})$, 粒厚 $5.91 \pm 0.43 \mathrm{~mm}$ （5.11〜6.68 mm）であった（表 1).

(2) 実験装置

種子繰出し用実験装置を図 1 亿示す。本装置 は，目皿式播種機（アグリテクノ矢崎製 TDR）の 繰出し軸に，フレキシブルカップリング（オリエ ンタルモータ製 USM206-401W2J)，ギアヘッド （オリエンタルモータ製 2GN18k），AC 小型標準 モータ（オリエンタルモータ製 USM206-401W2J) の順で取り付け, 主電源 $(\mathrm{AC} 100 \mathrm{~V})$ から汎用電源 （オムロン製 S82J-5524），スピードコントローラ （オリエンタルモー夕製 MSP-1W）を介して傾斜 目皿をモー夕駆動させた。モー夕（目皿）の回転 速度は可変抵抗器 (COSMOS 製 RV24YN 20S B $503,50 \mathrm{k} \Omega)$ によって制御し, 数值はモー夕回転 速度表示計（オリエンタルモー夕製 SDM496）に 出力した. 市販品と同じ姿勢 (目皿傾斜角 $31^{\circ}$ ) で 実験台に固定した。

(3) 試験方法

表 2 に供試した傾斜目皿の種類と特徵, 試験条 件を示す.

傾斜目皿の直径は全試験区で共通とし，市販品 と同じ $169 \mathrm{~mm}$ のものを使用した.

(1) 播種穴ピッチ円の直径㧍よび穴径が種子繰出 し率に及ぼす影響

同じ円周上に 8 等分配置した，穴数 8 の 1 粒播
き用傾斜目皿に大粒を供試した。傾斜目皿の厚さ は, 市販品の大粒用と同じ $6 \mathrm{~mm}$ (平均粒厚よりむ 約 $1 \mathrm{~mm}$ 薄いもの) とした. 傾斜目皿の種類は $\mathrm{a}$ $\mathrm{d}$ を供試し, 穴径 D は $10.5 \mathrm{~mm}, 11.5 \mathrm{~mm}, 12.5 \mathrm{~mm}$ の 3 通りに変え, 各々の項目と種子繰出し率の関係 を調べた. 傾斜目皿の回転速度 R は 15〜 54 rpm まで 6 通りとしたが，穴径を既製品より大きめに 設定した $\mathrm{D}=11.5 \mathrm{~mm}$ と $12.5 \mathrm{~mm}$ については, 高 速播種を目的とした本研究の主旨に従い, $\mathrm{R}=35$ 〜 $54 \mathrm{rpm}$ まで 3 通りとした。播種穴ピッチ $\mathrm{P}$ は $\mathrm{L} \times \pi$ を穴数で除して求め, 38.1 57.7 mm であっ た。播種穴周速度 $\mathrm{PV}$ は $\mathrm{L} \times \pi \times \mathrm{R}$ を 60 で除して 求め, $7.6 \sim 41.6 \mathrm{~cm} / \mathrm{s}$ であった.

(2) 粒径が種子繰出し率に及ぼす影響

穴数 8 の 1 粒播き用傾斜目皿に小粒を供試し た. 傾斜目皿の厚さは, 市販品の小粒用と同じ 5 $\mathrm{mm}$ (平均粒厚よりも約 $1 \mathrm{~mm}$ 薄いもの) と $6 \mathrm{~mm}$ (平均粒厚と同程度のもの) とした. 傾斜目皿の種

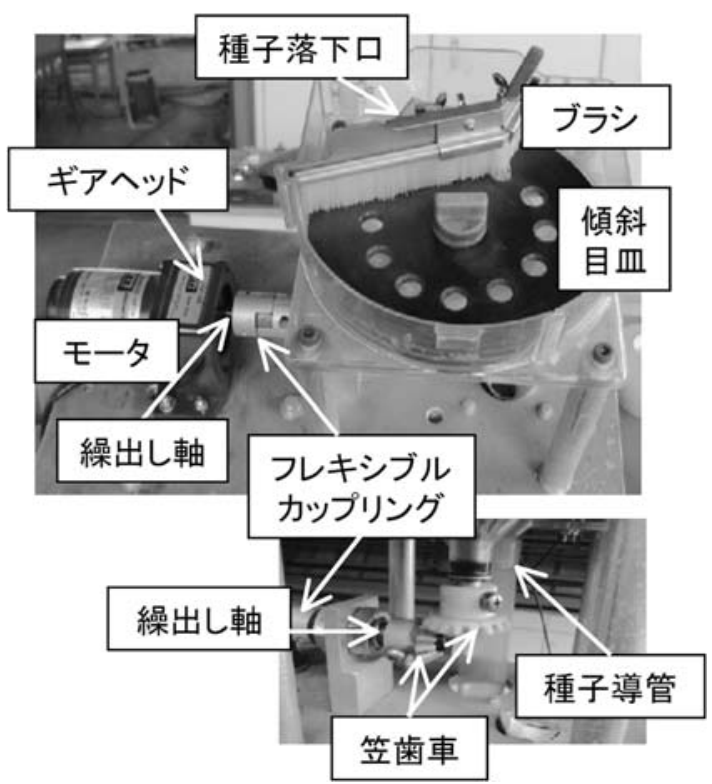

図 1 種子繰出し用実験装置

表 1 供試種子の長さ, 幅および厚さ

\begin{tabular}{|c|c|c|c|c|c|c|}
\hline & \multicolumn{3}{|c|}{ 大粒（夕チナガ八） } & \multicolumn{3}{|c|}{ 小粒（Bragg） } \\
\hline & 平均值（標準偏差） & 最大值 & 最小値 & 平均值（標準偏差） & 最大值 & 最小値 \\
\hline 長さ (mm) & $8.72( \pm 0.42)$ & 9.66 & 7.86 & $7.19( \pm 0.36)$ & 7.88 & 6.10 \\
\hline 幅 (mm) & $8.34( \pm 0.31)$ & 8.92 & 7.76 & $6.77( \pm 0.35)$ & 7.59 & 5.76 \\
\hline 厚さ (mm) & $7.16( \pm 0.42)$ & 7.98 & 6.27 & $5.91( \pm 0.43)$ & 6.68 & 5.11 \\
\hline
\end{tabular}


表 2 供試した傾斜目皿の種類と特徴, 試験条件

\begin{tabular}{|c|c|c|c|c|c|c|c|c|c|c|}
\hline \multirow{5}{*}{$\begin{array}{l}\text { 同じ円周上に配置した播種穴の数 } \\
\text { 播種方法 } \\
\text { 穴数 } \\
\text { 供試品種 (タチナガ八:大粒, Bragg : 小粒) } \\
\text { 播種穴の直径 (穴径) D (mm) } \\
\text { 傾斜目皿の厚さ (mm) } \\
\text { 傾斜目皿の種類 } \\
\text { 播種穴ピッチ円の直径 L (mm) } \\
\text { 播種穴ピッチ P (mm) }\end{array}$} & \multicolumn{10}{|c|}{8} \\
\hline & \multicolumn{6}{|c|}{$\begin{array}{c}1 \text { 粒播き } \\
8\end{array}$} & \multicolumn{4}{|c|}{$\begin{array}{c}2 \text { 粒播き } \\
16\end{array}$} \\
\hline & \multicolumn{4}{|c|}{$\begin{array}{c}\text { 大粒 } \\
10.5,11.5,12.5\end{array}$} & \multicolumn{2}{|c|}{$\begin{array}{c}\text { 小粒 } \\
9.5,10.0,10.5 \\
5 \mathrm{~mm}, 6 \mathrm{~mm} \\
\end{array}$} & \multicolumn{4}{|c|}{$\begin{array}{c}\text { 大粒 } \\
10.5(\mathrm{G}), 12.5(\mathrm{H}) \\
6 \mathrm{~mm}\end{array}$} \\
\hline & $\mathrm{a}$ & $\mathrm{b}$ & $\mathrm{c}$ & $\mathrm{d}$ & $\mathrm{e}$ & $\mathrm{f}$ & \multicolumn{2}{|c|}{$\mathrm{g}$} & \multicolumn{2}{|c|}{$\mathrm{h}$} \\
\hline & $\begin{array}{c}97 \\
38.1\end{array}$ & $\begin{array}{c}113 \\
44.4\end{array}$ & $\begin{array}{c}130 \\
51.0\end{array}$ & $\begin{array}{c}147 \\
57.7\end{array}$ & $\begin{array}{c}97 \\
38.1\end{array}$ & $\begin{array}{c}130 \\
51.0\end{array}$ & $\begin{array}{c}103 \\
40.4\end{array}$ & $\begin{array}{c}130 \\
51\end{array}$ & $\begin{array}{c}97 \\
38.1\end{array}$ & $\begin{array}{r}126 \\
49.5\end{array}$ \\
\hline 目 & \multicolumn{10}{|c|}{ 播種穴周速度 PV（cm/s） } \\
\hline 15 & 7.6 & 8.9 & 10.2 & 11.5 & - & - & 8.1 & 10.2 & - & - \\
\hline 24 & 12.2 & 14.2 & 16.3 & 18.5 & - & - & 12.9 & 16.3 & - & - \\
\hline 30 & 15.2 & 17.7 & 20.4 & 23.1 & - & - & 16.2 & 20.4 & - & - \\
\hline 36 & 18.3 & 21.3 & 24.5 & 27.7 & - & - & 19.4 & 24.5 & 18.3 & 23.8 \\
\hline 45 & 22.9 & 26.6 & 30.6 & 34.6 & - & - & 24.3 & 30.6 & 22.9 & 29.7 \\
\hline (rpm) & 27.4 & 31.9 & 36.8 & 41.6 & 27.4 & 36.8 & 29.1 & 36.8 & 27.4 & 35.6 \\
\hline 製品名* & \multicolumn{4}{|c|}{$\mathrm{A}-2, \quad \mathrm{~A}-3$} & & A-1 & B-2, & B-3 & & \\
\hline
\end{tabular}

\begin{tabular}{|c|c|c|c|c|c|c|c|}
\hline \multirow{2}{*}{\multicolumn{2}{|c|}{$\begin{array}{l}\text { 同じ円周上に配置した播種穴の数 } \\
\text { 播種方法 } \\
\text { 穴数 }\end{array}$}} & \multicolumn{3}{|c|}{12} & \multicolumn{3}{|c|}{16} \\
\hline & & $\begin{array}{c}1 \text { 粒播き } \\
12\end{array}$ & \multicolumn{2}{|c|}{$\begin{array}{c}2 \text { 粒播き } \\
24\end{array}$} & $\begin{array}{c}1 \text { 粒播き } \\
16\end{array}$ & \multicolumn{2}{|c|}{$\begin{array}{c}2 \text { 粒播き } \\
32\end{array}$} \\
\hline \multirow{4}{*}{\multicolumn{2}{|c|}{$\begin{array}{l}\text { 供試品種 (タチナガ八: 大粒, Bragg : 小粒) } \\
\text { 播種穴の直径 (穴径) D (mm) } \\
\text { 傾斜目皿の厚さ (mm) } \\
\text { 傾斜目皿の種類 }\end{array}$}} & \multicolumn{3}{|c|}{ 大粒 } & \multicolumn{3}{|c|}{ 大粒 } \\
\hline & & & \multicolumn{2}{|c|}{12.5} & & \multicolumn{2}{|l|}{12.5} \\
\hline & & & \multicolumn{2}{|c|}{$6 \mathrm{~mm}$} & \multicolumn{3}{|c|}{$6 \mathrm{~mm}$} \\
\hline \multirow{3}{*}{\multicolumn{2}{|c|}{$\begin{array}{l}\text { 傾斜目皿の種類 } \\
\text { 播種穴ピッチ円の直径 L }(\mathrm{mm}) \\
\text { 播種穴ピッチ P (mm) }\end{array}$}} & $\mathrm{i}$ & \multicolumn{2}{|c|}{$\mathrm{j}$} & $\mathrm{k}$ & \multicolumn{2}{|c|}{1} \\
\hline & & 97 & 97 & 126 & 97 & 97 & 126 \\
\hline & & 25.4 & 25.4 & 33.0 & 19.0 & 19.0 & 24.7 \\
\hline \multicolumn{2}{|l|}{ 目 } & \multicolumn{6}{|c|}{ 播種穴周速度 PV（cm/s） } \\
\hline 血. & 15 & - & - & - & - & - & - \\
\hline 回 & 24 & - & - & - & - & - & - \\
\hline 転 & 30 & - & - & - & - & - & - \\
\hline 数 & 36 & - & - & - & - & - & - \\
\hline $\mathrm{R}$ & 45 & - & - & - & - & - & - \\
\hline (rpm) & 54 & 27.4 & 27.4 & 35.6 & 27.4 & 27.4 & 35.6 \\
\hline
\end{tabular}

製品名*

*: A-1 は D=8 mm, A-2 は D=10.5 mm, A-3 は D=12.0 mm, B-2 は D=10.5 mm, B-3 は D=12.0 mmのもの.空欄は 対応する製品なし. 傾斜目皿の出荷割合は, B- 2 が $80 \%, A-1 \sim A-3$ ， および B-3 が各 $5 \%$ (メーカへの聞き取りによる). 傾斜目皿の厚さは，A-1 が 5 mm, A-2, A-3, B-2, B-3 が 6 mm.「一」は試験設定なし.

類は e とf を供試し, 穴径 D は $9.5 \mathrm{~mm}, 10.0 \mathrm{~mm}$, $10.5 \mathrm{~mm}$ の 3 通りに変えた. $\mathrm{R}=54 \mathrm{rpm}(\mathrm{P}=38.1$ $\sim 51.0 \mathrm{~mm}, \mathrm{PV}=27.4 \sim 36.8 \mathrm{~cm} / \mathrm{s}$ ）に扔いて各項 目と種子繰出し率の関係を調べた.

(3) 高速播種対応型の傾斜目皿の性能試験

出荷される傾斜目皿の $85 \%$ は 2 粒播き用であ り, $\mathrm{L}=103 \mathrm{~mm}$ と $\mathrm{L}=130 \mathrm{~mm}$ の各々に $\phi 10.5 \mathrm{~mm}$ の播種穴を 8 等分配置した穴数 16 の大粒用（傾 斜目皿の種類 g, 以後，慣行目皿）がその $95 \%$ を 占める。 そこで，(1) の試験結果に基づいて改良し た， $\mathrm{L}=97 \mathrm{~mm}$ と $\mathrm{L}=126 \mathrm{~mm}$ の円周上の各々に $\phi 12.5 \mathrm{~mm}$ の播種穴を 8 等分配置した穴数 16 の 大粒用（傾斜目皿の種類 $\mathrm{h}$, 以後, 改良目血）之慣
行目皿を用い (図 2), $R=15 \sim 54 \mathrm{rpm}(\mathrm{PV}=8.1$ ～ $36.8 \mathrm{~cm} / \mathrm{s}$ ) において種子繰出し率を調べた。な お，改良目皿については，高速播種を目的とした 本研究の主旨に従い, $\mathrm{R}=36 \sim 54 \mathrm{rpm}$ とした.

また，播種穴周速度をさらに低下させる方法と して, 改良目血と同じ播種穴の配置で, 穴数 16 (同 じ円周上に 8 等分配置) を 24 (同 12 等分配置) と 32 (同 16 等分配置) に変えたもの, 傾斜目血の種 類では $\mathrm{i} \sim 1$ を供試し，播種穴ピッチ 19.0 (同じ円 周上に 16 等分配置) $49.5 \mathrm{~mm}$ (同 8 等分配置) $(\mathrm{PV}=27.4 \sim 35.6 \mathrm{~cm} / \mathrm{s})$ において種子繰出し率と の関係を調べた。併せて，内穴と外穴の種子繰出 し率の差を把握するため, 内穴 $(\mathrm{L}=97 \mathrm{~mm})$ のみ 
に $\phi 12.5 \mathrm{~mm}$ の播種穴を開けた穴数 $8,12,16$ の 1 粒播き用を供試した。

(4) 種子繰出し率

傾斜目皿の性能を評価する指標として，種子繰 出し率（\%) を求めた. 種子繰出し率は種子落下 口を通過した穴数に対して地面に落ちた（播種さ れた）粒数の比とし，目皿ホッパー（図 1 では省 略）のシャッターを開けて傾斜目皿上にダイズ種 子（150〜 $170 \mathrm{~g}$ 程度）を排出した後，手動で傾斜 目皿を 1 回転させ，これを起点として種子繰出し 用実験装置で傾斜目皿を 20 回転させた時の值と した. 試験は各区とも $2 \sim 3$ 回ずつ繰り返した.

\section{2）圑場試験}

供試圃場は, 農研機構中央農業総合研究セン ター内のダイズ収穫後不耕起圃場および耕起圃場 (10 a) とした. 作業機は目皿式播種機 (型式 TDR) を装備した 4 条用の不耕起播種試作機 (国立 2008) を用い, 出力 $22 \mathrm{~kW}$ （Y 社製 RS-30）のトラク夕 に装着した。試験区は，改良目皿による処理区お よび慣行目皿による対照区とした．供試種子は大 粒とした。

不耕起圃場では，慣行目血と改良目血を各 1 条 にセットし(残り 2 条は別試験で利用), 作業速度 を $0.5 \sim 1.7 \mathrm{~m} / \mathrm{s}$ まで 5 水準に变え，播種穴周速度 $\mathrm{PV}=7.3 \sim 26.1 \mathrm{~cm} / \mathrm{s}$, 内穴と外穴の播種穴周速度 の平均值 (以後, PVave) では $8.3 \sim 26.9 \mathrm{~cm} / \mathrm{s}$ の 条件で種子繰出し率との関係を調べた。試験は作 業速度毎に 2 回繰り返した。

耕起圃場では, 両端 2 条に改良目皿をセット し (残り 2 条は別試験で利用)，作業速度を $0.5 \sim$ $2.0 \mathrm{~m} / \mathrm{s}$ まで 5 水準に変え, $\mathrm{PV}=7.5 \sim 32.0 \mathrm{~cm} / \mathrm{s}$ $(\mathrm{PVave}=8.1 \sim 29.7 \mathrm{~cm} / \mathrm{s})$ において種子繰出し率 との関係を調べた. 試験は作業速度毎に 1 回行っ た.

固場での種子繰出し率は, 平均株間 $14 \mathrm{~cm}$ で $30 \mathrm{~m}$ 走行した時の設定播種量に対する播種粒数 (地面に落下した粒数) の比とし，作業速度毎に值 を求めた.

\section{3. 結果および考察}

1）播種穴ピッチ円の直径および穴径が種子繰出 し率に及ぼす影響

図 3 に, 大粒, 穴径 $\mathrm{D}=10.5 \mathrm{~mm}$ において, 播 種穴ピッチ円の直径 L を 97〜 $147 \mathrm{~mm}$ まで 4 通

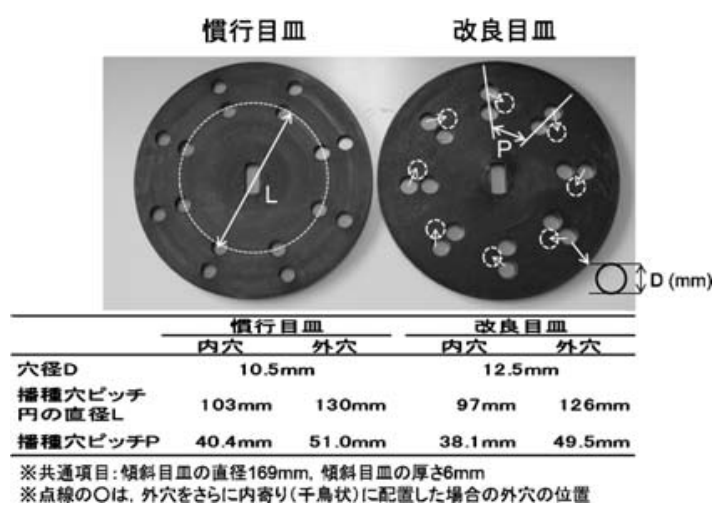

困 2 大粒用慣行目皿之改良目皿の特徵 ( 2 粒播き用)

りに変えた時の種子繰出し率を示す.

種子繰出し率 $95 \%$ (目標值) 以上となる播種穴 周速度 $\mathrm{PV}$ は, $\mathrm{L}=97 \mathrm{~mm}$ および $\mathrm{L}=113 \mathrm{~mm}$ では およそ $20 \mathrm{~cm} / \mathrm{s}$ 以下, $\mathrm{L}=130 \mathrm{~mm}$ と $\mathrm{L}=147 \mathrm{~mm}$ では，各々， $22 \mathrm{~cm} / \mathrm{s}$ 以下， $25 \mathrm{~cm} / \mathrm{s}$ 以下であっ た. 播種穴周速度が同じ場合は播種穴ピッチ円の 直径が大きいほど種子繰出し率が高まった.

一方，傾斜目皿の回転速度 $\mathrm{R}=54 \mathrm{rpm}$ における 種子繰出し率は, $\mathrm{L}=97 \mathrm{~mm}(\mathrm{PV}=27.4 \mathrm{~cm} / \mathrm{s})$ で は $73.4 \%, \mathrm{~L}=113 \mathrm{~mm}(\mathrm{PV}=31.9 \mathrm{~cm} / \mathrm{s})$ では $60 \%$ であり, $\mathrm{L}=130 \mathrm{~mm}(\mathrm{PV}=36.8 \mathrm{~cm} / \mathrm{s})$ と $\mathrm{L}=147$ $\mathrm{mm}(\mathrm{PV}=41.6 \mathrm{~cm} / \mathrm{s})$ では, 各々, $43.8 \%, 51.9 \%$ に減少した。傾斜目皿の回転速度を $54 \mathrm{rpm}$ まで 速めた場合には，播種穴ピッチ円の直径が小さい ほど播種穴周速度が低下し, 種子繰出し率が向上 した. 当初の仮説の通り，播種穴は傾斜目皿の外 側にあるほうが種子が供給されやすかったが，播 種穴を傾斜目皿の中心よりに配置して播種穴周速 度を低下させたほうが種子繰出し率はさらに高 まった。

但し，播種穴ピッチ円の直径を $97 \mathrm{~mm}$ まで小 さくして播種穴周速度を低下させても, 下名迫ら （1989）がダイズ用目皿式播種機の設計要素とし て提示した種子の最大径（長さ）よりも $1 \sim 2 \mathrm{~mm}$ 大きい程度の穴径では, 種子繰出し率が低下しや すかった.

そこで, $\mathrm{L}=97 \mathrm{~mm}(\mathrm{PV}=27.4 \mathrm{~cm} / \mathrm{s})$ において 穴径 D を $10.5 \mathrm{~mm}$ から $11.5 \mathrm{~mm}$ と $12.5 \mathrm{~mm}$ に変 え, 種子繰出し率との関係を調べた（図 4).

その結果, Dの值が大きくなるのに従い, 種子 繰出し率が高まった. $\mathrm{D}=12.5 \mathrm{~mm}$ として, 穴径を 


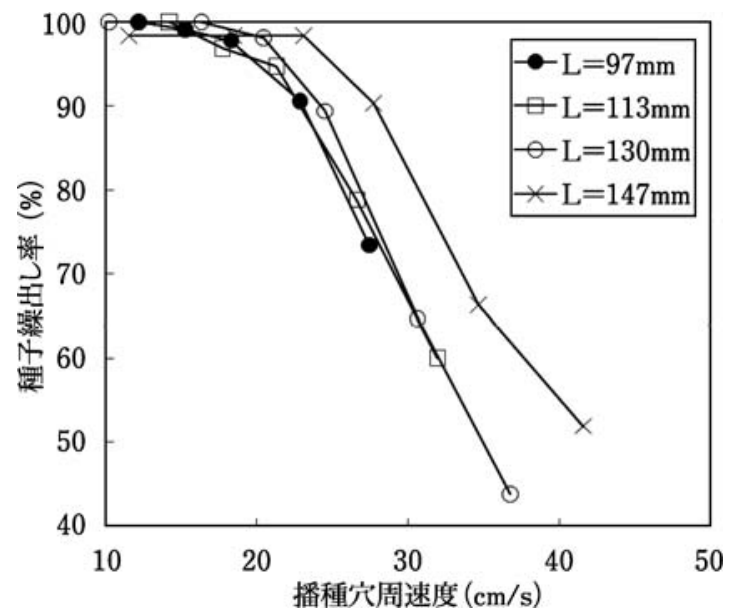

図 3 播種穴ピッチ円の直径と播種穴周速度が 種子繰出し率に及ぼす影響 (大粒, $\mathrm{D}=$ $10.5 \mathrm{~mm}$ )

粒厚の最小值（100 粒での最小値）の約 2 倍, また は種子の最大径（長さ）の平均值よりも $4 \mathrm{~mm}$ 程 度大きくすると, $\mathrm{PV}=27.4 \mathrm{~cm} / \mathrm{s}$ に達しても種子 繰出し率がほほ $100 \%$ に保たれた。なお，D=12.5 $\mathrm{mm}$ において $\mathrm{L}=147 \mathrm{~mm}(\mathrm{PV}=41.6 \mathrm{~cm} / \mathrm{s})$ とし た場合の種子繰出し率は $90 \%$ であった（データ は省略).

\section{2）粒径が種子繰出し率に及ぼす影響}

$\mathrm{L}=97 \mathrm{~mm}(\mathrm{PV}=27.4 \mathrm{~cm} / \mathrm{s})$ における種子繰出 し率は，小粒を用いた場合，供試した傾斜目皿の 厚さを問わず，穴径を $\mathrm{D}=10.5 \mathrm{~mm}$ にするとほぼ 100\%になった (図 5). すなわち, 穴径は，大粒と ほぼ同様に，種子の粒厚の最小值（100 粒での最 小値）の約 2 倍，または種子の最大径（長さ）の 平均值よりも 3 $4 \mathrm{~mm}$ 程度大きくするのが適正 であった。

また, $\mathrm{D}=10.0 \mathrm{~mm}$ の時と $\mathrm{D}=10.5 \mathrm{~mm}$ の時の 種子繰出し率の差は, 傾斜目皿の厚さを平均粒厚 より $1 \mathrm{~mm}$ 程度薄くした場合が $5.1 \%$ であったの に対し，平均粒厚と同程度にした場合が $3.1 \%$ で あった。小粒を供試した場合は，傾斜目皿の厚さ を平均粒厚と同程度にしたほうが穴径による種子 繰出し率の差が小さく, 種子繰出し率が安定し た。

一方, $\mathrm{L}=130 \mathrm{~mm}(\mathrm{PV}=36.8 \mathrm{~cm} / \mathrm{s})$ における 種子繰出し率は, $\mathrm{D}=10.5 \mathrm{~mm}$ の時, $107.5 \%$ であ り，傾斜目皿の厚さを平均粒厚と同程度にした場

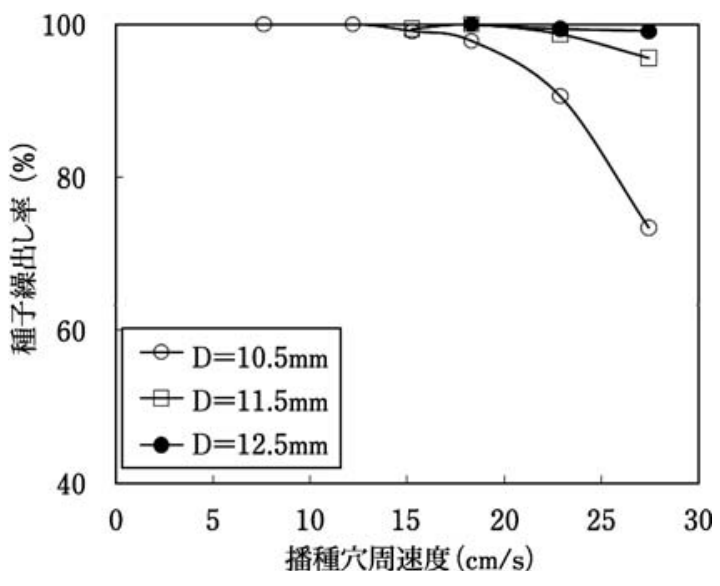

図 4 穴径と播種穴周速度が種子繰出し率に 及ぼす影響（大粒， $\mathrm{L}=97 \mathrm{~mm}$ ）

合は播種穴への種子の供給が過剩であった。この 原因は，播種穴の大きさが種子の厚さの最小值の 2 倍以上となり，1つの播種穴から 2 粒同時に繰 り出されたケースが生じたためと考えられる.

これに対し, $\mathrm{D}=10.0 \mathrm{~mm}$ の時の種子繰出し率は 91.3\% であり, D=10.5 mm の時の值よりも $16.2 \%$ 低下した。また，傾斜目皿の厚さを平均粒厚より $1 \mathrm{~mm}$ 程度薄くした場合は, $\mathrm{D}=10.5 \mathrm{~mm}$ として 屯種子繰出し率は $86.3 \%$ に低下した。つまり, 播 種穴ピッチ円の直径を大きくすると種子繰出し率 が不安定になった．播種穴周速度が大幅に高まっ たためと推察される.

以上をまとめると, 種子繰出し率の安定化で は，播種穴ピッチ円の直径を大きくすることより あ播種穴周速度を低下させることがより重要であ り，その手段として播種穴ピッチ円の直径を小さ くする方法が有効であった。また種子繰出し率を 高めるには，穴径は供試種子における粒厚の最小 值の約 2 倍加種子の最大径（長さ）の平均值より 屯 3 4 $\mathrm{mm}$ 程度大きくすること, 傾斜目皿の厚 さは, 大粒では平均粒厚より $1 \mathrm{~mm}$ 薄くし, 小粒 では平均粒厚と同程度にすることが必要であり， 播種粒数が低下しない播種穴周速度の許容值は $20 \sim 25 \mathrm{~cm} / \mathrm{s}$ 程度であった。

3）高速播種対応型の大粒 2 粒播き用傾斜目皿に よる性能試験の結果

（1）室内試験

慣行目㿼では， $\mathrm{R}=24 \mathrm{rpm}$ 以上， PVave $=14.6$ 


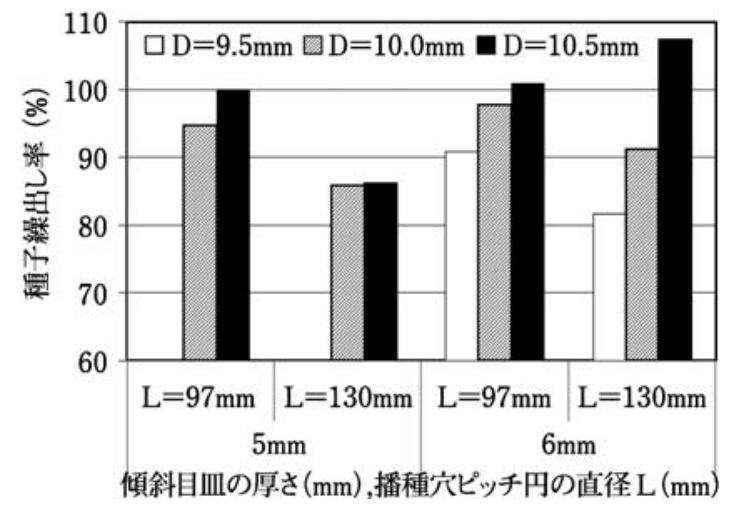

図 5 傾斜目血の厚さ, 穴径および播種穴ピッ チ円の直径が種子繰出し率に及ぼす影響 （小粒， $\mathrm{R}=54 \mathrm{rpm}$ )

$\mathrm{cm} / \mathrm{s}$ (内穴 $12.9 \mathrm{~cm} / \mathrm{s}$, 外穴 $16.3 \mathrm{~cm} / \mathrm{s}$ ) 以上に達 すると種子繰出し率が低下し始め, $\mathrm{R}=54 \mathrm{rpm}$,

PVave $=32.9 \mathrm{~cm} / \mathrm{s}$ (内穴 $29.1 \mathrm{~cm} / \mathrm{s}$, 外穴 36.8 $\mathrm{cm} / \mathrm{s}$ ) まで傾斜目皿の回転速度または播種穴周 速度が速まると，種子繰出し率は $43.8 \%$ になった (図6).

これに対し改良目皿の種子繰出し率は, $\mathrm{R}=54$ $\mathrm{rpm}, \mathrm{PVave}=31.5 \mathrm{~cm} / \mathrm{s}$ (内穴 $27.4 \mathrm{~cm} / \mathrm{s}$, 外穴 $35.6 \mathrm{~cm} / \mathrm{s}$ ) に抢いて $97.7 \%$ であり, 高く保たれた.

なお， 2 粒播き用の傾斜目皿は，通常，図 2 に示 すように内穴と外穴が平行に等分配置されている が，外穴の播種穴周速度をさらに低下させるた め, 点線の丸のように外穴を内穴と千鳥に配置 し, 外穴の $\mathrm{L}=126 \mathrm{~mm}$ を $\mathrm{L}=113 \mathrm{~mm}$ まで小さ くすると，種子繰出し率は $99.2 \%$ に高まった。播 種穴を面取りすると種子繰出し率はさらに高ま り，99.8\%になった（デー夕は省略）。

図 7 に改良目皿の穴数 16 (同じ円周上に 8 等分 配置）を24（同 12）押よび $32 （$ 同 16）に変えた 場合，抢よびその内穴のみを使用した場合の $\mathrm{R}=$ $54 \mathrm{rpm}, \mathrm{PVave}=31.5 \mathrm{~cm} / \mathrm{s}$ (内穴 $27.4 \mathrm{~cm} / \mathrm{s}$, 外穴 $35.6 \mathrm{~cm} / \mathrm{s}$ ) における種子繰出し率を示す.

穴数 16 (播種穴ピッチ $\mathrm{P}=38.1 \sim 49.5 \mathrm{~mm}$ ) にお ける種子繰出し率は $98.8 \%$ であり, 穴数 $32(\mathrm{P}=$ 19.0～24.7 mm）として屯種子繰出し率は $97.0 \%$ で高かった。

内穴 $(\mathrm{L}=97 \mathrm{~mm})$ のみを使用した時の種子繰出 し率は，穴数を問わず，ほぼ $100 \%$ であったこと から, 種子繰出し率の低下は外穴 $(\mathrm{L}=126 \mathrm{~mm})$ によるあのである。但し，播種穴ピッチが $20 \mathrm{~mm}$

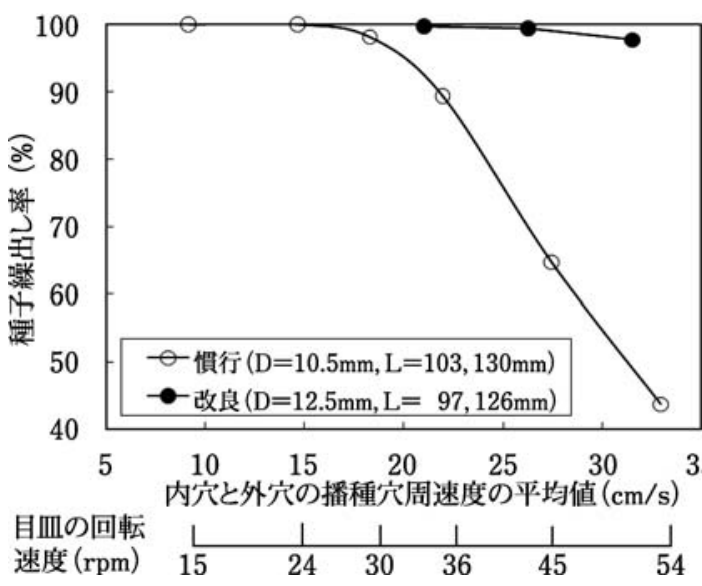

図 6 大粒用慣行目皿之改良目皿による播種 穴周速度と種子繰出し率の関係

程度あれば，既存の報告（下名迫ら 1989）之同様 に，種子繰出し率に及ぼす影響は少なかった。

(2) 固場試験

不耕起圃場における種子繰出し率は, 慣行目血 を使用した場合, 作業速度 $1.4 \mathrm{~m} / \mathrm{s}$ 以下, 内穴と外 穴の播種穴周速度の平均值 PVave が $22.3 \mathrm{~cm} / \mathrm{s}$ (内穴の $P V=19.7 \mathrm{~cm} / \mathrm{s}$, 外穴 $P V=24.8 \mathrm{~cm} / \mathrm{s}$ ) 以 下では平均して 53.0\% (49.5 56.3\%) であり, 作 業速度による特定の傾向は認められなかった（図 8). 作業速度 $1.7 \mathrm{~m} / \mathrm{s}$ まで速めた時には, 種子繰 出し率は $38.3 \%$ まで低下した。

これに対し, 改良目皿を使用した場合の種子繰 出し率は, 作業速度 $1.7 \mathrm{~m} / \mathrm{s}$ 以下では平均して 82.9\% (74.5〜 90.6\%) であり，慣行目皿を平均で $30 \%$ 程度上回った。但し, 改良目皿においても慣 行目皿を使用した場合と同様に，作業速度を問わ ず，種子繰出し率が低下した。この原因は，圃場 の凹凸などによって傾斜目皿を駆動する鎮圧輪が 空転したためと考えられる.

一方, 耕起圃場に打ける種子繰出し率は, 改 良目皿を使用した場合，作業速度 $1.5 \mathrm{~m} / \mathrm{s}$ 以下， PVave $=21.5 \mathrm{~cm} / \mathrm{s}$ (内穴 $19.9 \mathrm{~cm} / \mathrm{s}$, 外穴 23.1 $\mathrm{cm} / \mathrm{s}$ ) 以下ではほぼ $100 \%$ であった。作業速度 $2.0 \mathrm{~m} / \mathrm{s}, P V a v e=29.7 \mathrm{~cm} / \mathrm{s}$ (内穴 $27.5 \mathrm{~cm} / \mathrm{s}$, 外 穴 $32.0 \mathrm{~cm} / \mathrm{s}$ ) まで速めると, 種子繰出し率は 92.4 \%に低下した。なお，この值は図 7 の室内におけ る PVave $=31.5 \mathrm{~cm} / \mathrm{s}$ での值, $97.7 \%$ と比べてや や低かったが，理由は不明である。また室内試験 之同様に，播種粒数が低下しない播種穴周速度の 


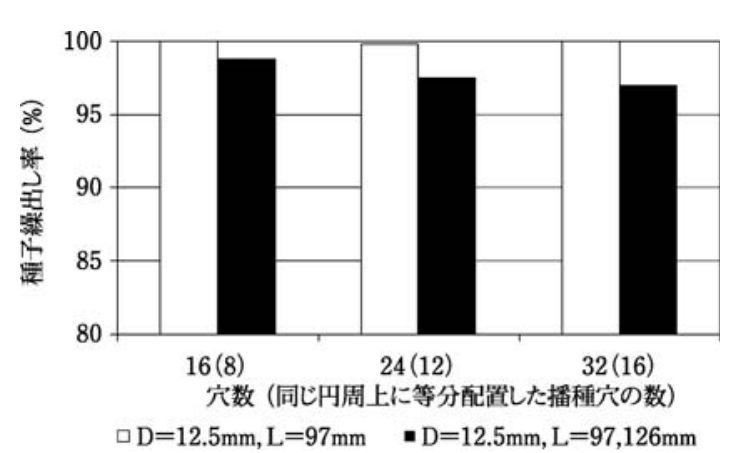

図 7 大粒用改良目皿において穴数が種子繰出 し率に及ぼす影響（大粒， $\mathrm{R}=54 \mathrm{rpm}$ ）

許容值は $20 \sim 25 \mathrm{~cm} / \mathrm{s}$ 程度であった。

以上，室内試験結果に基づいて高速播種用 2 粒 播き傾斜目皿（穴数 16）を試作し，作業速度 1.5 $\mathrm{m} / \mathrm{s}$ 以下では播種粒数が低下しなかった。この值 は従来の作業速度 $0.8 \mathrm{~m} / \mathrm{s}$ の約 2 倍であった。ま た，播種穴ピッチ $20 \mathrm{~mm}$ 程度を目安に穴数を増 やすと，さらに作業速度を速めることができる. 但し，この際，スリップ等圃場走行に伴って生じ る種子繰出し率の低下に関しては, 別途対策が必 要である.

なお，本研究では検討を行わなかったが，傾斜 目皿の外周付近に播種穴を配置した場合でも播種 穴ピッチ $20 \mathrm{~mm}$ 程度を目安に穴数を増やすこと で播種穴周速度を低下でき, 高速播種に対応可能 と推察される. しかし, 播種穴ピッチ円の直径を 小さくしたほうが播種穴周速度が低下する分，よ り速い播種作業へ対応できる. その一方で, 市販 の目皿式播種機では播種穴ピッチ円の直径を小さ くすると, 種子排出口の形状によって播種した種 子がばらつきやすい可能性がある。このため, 播 種穴ピッチ円の直径が種子のばらつき（播種精 度）に及ぼす影響や，種子のばらつきが生育収量 に及ぼす影響については別途検討が必要である.

\section{4. 摘要}

現場に普及する傾斜回転目皿式播種機による播 種作業を高速化するため, 室内の静置条件下にお いて高速播種に適した傾斜回転目皿の特徵を明ら かにするともに，高速播種用傾斜目皿を試作し， 室内と圃場でその性能を評価した。

1）播種穴周速度が同じ場合は播種穴ピッチ円の 直径が大きいほど種子繰出し率が高まった

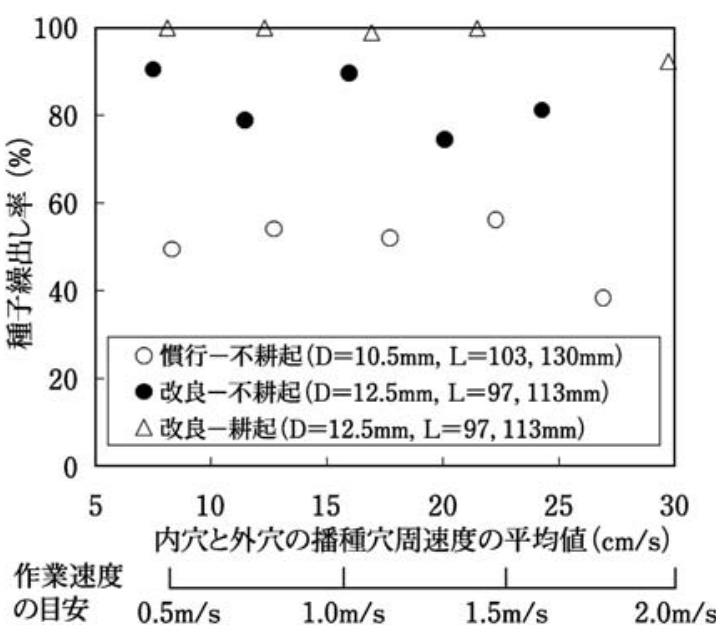

困 8 作業速度が種子繰出し率に及ぼす影響の 大粒用慣行目皿之改良目皿の比較

が, 播種穴ピッチ円の直径を小さくして播種 穴周速度を低下させたほうが種子繰出し率が より高まった。

2）播種穴ピッチ円の直径を小さくしても穴径が 小さいと種子繰出し率が低下しやすかった が, 穴径を, 供試種子における粒厚の最小值の 約 2 倍, または種子の最大径の平均值よりも 3 4 $\mathrm{mm}$ 程度大きくすると, 種子繰出し率が 高く保たれた。

3）大粒では平均粒厚より $1 \mathrm{~mm}$ 薄い傾斜目皿を, 小粒では平均粒厚と同程度の傾斜目皿を使用 すると, 種子繰出し率が安定した。

4) 大粒 2 粒播き用の傾斜目血（穴数 16）を試作 し, 圃場試験において, 播種穴周速度 20２5 $\mathrm{cm} / \mathrm{s}$ 以下, 作業速度 $1.5 \mathrm{~m} / \mathrm{s}$ 以下の時, 播種 粒数が低下しなかった。作業速度は従来の約 2 倍に達した。播種穴ピッチ $20 \mathrm{~mm}$ 程度を目 安に穴数を増やすと, さらに, 作業速度を速め ることができる.

\section{謝辞}

本研究の実施にあたって, 農研機構生研支援セ ンターの梅田直円博士には, 実験装置の試作でご 協力をいただいた。 また，アグリテクノ矢崎(株) には傾斜目皿の試作でご協力をいただいた。農研 機構中央農業総合研究センターの田澤純子博士に は，種子を提供していただいた。ここに記して謝 意を表する。 


$$
\text { キーワード }
$$

穴径, 傾斜回転目皿, 傾斜回転目皿式播種機, 傾 斜目皿の厚さ, 作業速度, 種子繰出し率, 大豆, 播種穴周速度, 播種穴ピッチ, 播種穴ピッチ円の 直径

\section{引用文献}

岩㴊哲也・田中浩平・尾形武文 (2006) : 大豆の 3 粒点播に掞ける機械播種法の開発, 平成 15 年度九州沖縄農業研究成果情報 https : // gpw. naro. affrc. go.jp / cgi-bin / dnet / dnet. cgi? page $=$ linkframe\&id $=4(2011 / 3 / 04$ 閲 覧).

小嶋和雄 - 村田 敏 - 吉村克規 - 大久保淳一 （1966）：回転目皿式排種装置の研究（第 1 報）一播種板上の種子の分布について一, 農 機誌 28 (4)；208-211.

国立卓生（2008）: 軽量トラク夕に対応したダイ ズ不耕起播種同時排水システムの開発, 農業 機械学会関東支部第 44 回年次大会講演要旨, 52-53.

皆川 博（2006）：傾斜回転目皿式播種機による 大豆の定間隔播種技術, 平成 16 年度茨城県 農業総合研究所農業研究所主要成果 : http : //www.pref.ibaraki.jp/bukyoku/nourin/ noken/ (2011/03/04 閲覧).

永田雅輝 - 古池寿夫 ・ 岡田芳一 - 御手洗正文 - 石 川勝美 (1989)：スイートコーン種子のパ ターン化による目皿セルの形状決定, 宮崎大 学農学部研究報告 36 (2) ; 329-337.

農林水産省ホームページ（2011）：食料・農業・ 農村基本計画の策定経過 : http : / / www. maff.go.jp/j/keikaku/(2011/03/04 閲覧).

岡村俊民-高畑英彦・伊藤道秋 - 外館隆二 (1966) : 傾斜回転目皿式播種装置のビート種子排出性 能について, 農機誌 28 (2)；90-94.

下名迫寬・矢治幸夫・中 精一・今園支和 (1989)： 高精度施肥播種技術に関する研究 第 1 報 種々の砕土条件における大豆用傾斜大径目皿 式播種機の適応性, 農作業研究 $24 ; 230-236$.

常松 栄・岡村俊民・太田 亨 (1958)：ティ ラー用（傾斜回転目皿式）ビート播種機に関
する実験, 北海道大学農学部紀要 $3(1) ; 15-$ 25.

\section{Summary}

To achieve high-speed seeding using the conventional inclined-cell-plate soybean seeder now on the market, we need to improve the filling of the holes in the cell plate with seeds. A laboratory experiment showed that the seeding rate (the number of seeds that reached the ground through the holes) increases as the peripheral velocity (PV) of the circle of the seed holes decreases, i.e. as the distance from the center of the inclined-plate to the seed holes. Also, increasing the number of seed holes (to 20-mm intervals) helps to lessen the PV. Furthermore, to achieve a high seeding rate, the seed-hole diameter should be twice the minimum of the average diameters, or 3 to $4 \mathrm{~mm}$ larger than the maximum of the average lengths, of 100 seeds. The optimum plate thickness was determined to be $1 \mathrm{~mm}$ thinner than the average seed diameter for large seeds, and the same as the average for small seeds. On the basis of these results, an inclined-cell-plate with 16 holes was made for use with a high-speed double feeder for large seeds and tested in the field. The seeding rate remained high when the $\mathrm{PV}$ was below 20 to $25 \mathrm{~cm} / \mathrm{s}$, achieving a seeder working speed of $1.5 \mathrm{~m} / \mathrm{s}$. This was twice the speed of the conventional inclined-cell-plate soybean seeder available on the market. We concluded that the new inclined-cell-plate can be used to improve working efficiency of the soybean seeder.

\section{Key Words}

cell-plate thickness, diameter of seed-holes circle, inclined cell-plate, inclined-plate soybean seeder, peripheral velocity of seed-hole circle, seed-hole diameter, seed-hole interval, seeding rate, soybean, working speed 